\title{
BUNKERS OF THE SPANISH WAR: FROM THE REARGUARD TO THE TECHNICAL CULTURE OF THE INTER-WAR PERIOD. THE CASE OF CLOT DE GALVANY
}

\author{
A. Martínez-Medina ${ }^{1}$, J.A. Marco Molina ${ }^{2}$, P.J. Juan-Gutiérrez ${ }^{1}$, \\ ${ }^{1}$ DEGCP, Department of Graphic Expression, Theory and Projects, Higher Polytechnic School, \\ University of Alicante, Spain - andresm.medina@ua.es; pablo.juan@ua.es \\ ${ }^{2}$ University Institute of Geography, University of Alicante, Spain - ja.marco@ua.es
}

Commission II, WG II/8

KEY WORDS: Mediterranean Wall, Bunkers and Antiaircraft Systems, Coastal Defences, Military Heritage, Concrete Ruins, Modern Architecture, Architectural Typologies, Spanish Civil War (1936-1939).

\begin{abstract}
:
During the Spanish Civil War (1936-39) the Second Republic ordered to build, from the end of 1937, a series of military structures to protect the cities located on the Mediterranean coast from a hypothetical landing or air incursions of the national side. This set of defenses was organized in two lines: coastal and antiaircraft detachments on top of hills and bunkers on the coast. In this work we proceed to the drawing of the bunker CG-bk04.elc, located in Clot de Galvany (Elche), $8 \mathrm{~km}$ south of Alicante, next to Carabassí beach, whose shape and dimensions are relevant enough, and its state of repair is quite good. This bunker is part of a larger group with a total of ten bunkers (of which eight still stand) that tried to prevent the advance of the enemy. The exterior drawing has been done by photogrammetry and the interior one manually, due to the small dimensions of its spaces. This work is included in a larger plan to document all these defences that are part of our technical and material legacy, as real ruins of the first modern concrete architecture, since the original designs of these bunkers were lost at the end of the conflict and nothing remains in the Army archives about them.
\end{abstract}

\section{INTRODUCTION: UNDOCUMENTED BUNKERS}

During the Spanish Civil War, the new armaments of modern wars were tested on both sides: mass media (press, radio and cinema), political propaganda, all types of mobile machines (tanks and airplanes) and static concrete artefacts such as bunkers and antiaircraft and coast defence systems. In fact, the government of the Second Republic, decided to fortify the Mediterranean coast line at the end of 1937 (Gil, Galdón 2007) in order to defend the cities and the citizenship from the bombings that the Italian aviation (which supported the insurrecto side and was established on the island of Mallorca) launched on the Republican coast (Aracil, Villaroya 2010). This system of defences, constituted by bunkers and shelters, is called 'Muro Mediterráneo' (Martínez 2012) by its similarity with Atlantikwall (1942-44) This set of defenses was organized at two

heights: the bunkers were located on the beach, while the coastal and antiaircraft systems were located on top of the hills. These architectures, with an industrial origin, were executed taking as reference the manuals of the sapper engineers (Bartolomé 1932, Villar 1942). However, many drawings disappeared during the war, in particular, those related to the province of Alicante (where the last capital of the Second Republic was). In the Archive of the Marqués del Viso (Ciudad Real), which keeps most of the graphic documents of the conflict, no projects of the Spanish southeast are preserved. Thus, the case that concerns us is the restitution of the designs of the main bunker (fig. 1): a the military settlement located $8 \mathrm{~km}$ south of Alicante, in front of the beach, near the Santa Pola cape, which is erected to repel a hypothetical landing.

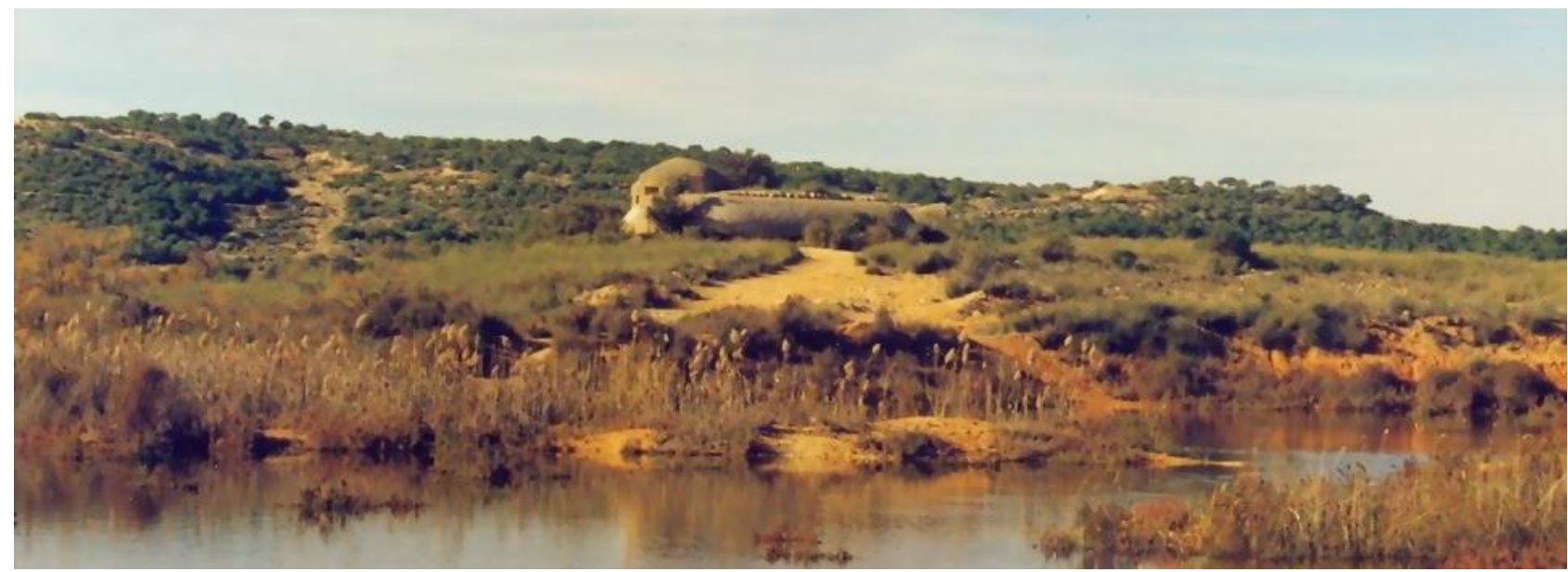

Figure 1. Main bunker (CG-BK04.elc), Clot de Galvany enclave (Elche, España), in the middle of the lagoon (photo: authors) 


\section{DESCRIPTION OF THE GEOGRAPHIC ENCLAVE}

\subsection{Geographical morphology of the enclave}

The enclave where our bunker is located is known as Clot de Galvany: a lake area near the beach that presents a series of particular geographical and geological features. The topographic conditions allowed the construction of a set of defences, coordinated from the main bunker, which is the largest in the settlement. This little system of defence is located on a small island in the lake that emerges to surface in the rainy years. This bunker is coordinated with seven other bunkers forming a line of defences that is coupled to the contours of the hills to control and defend the flat terrain that connected the sea with the national road -which could be reached by the enemy troops after a landing in the adjacent beach of Carabassí (fig. 2).

This Clot de Galvany area is located in the Baix Vinalopó region which, integrating the municipalities of Elx, Crevillent and Santa Pola, is perfectly individualized in the natural region: it constitutes the final part of a morphostructural unit with a great longitudinal development belonging to the Bética mountain range. This is the so-called Intrabética Trench or Intrabético furrow, that Hernández Pacheco (1934: 324) defined, in this more oriental end, as a tectonic depression open to the sea. And it is open because its eastern limit is solved by the alternation of prominent or tectonically raised sectors: on the one hand hills and mountains and, on the other one, low, sunken and occupied areas, constituting a wetlands place.
This happens between the Colmenars mountain range, to the north, and the Santa Pola one (with the cape as a prominent accident that dominates the horizon), at the southern end, or between the Santa Pola and the Molar mountain chains, where the Albufera extends from Elche-Salinas to Santa Pola, separated from the sea by a shoal and a dune cord.

However, in the first section, which is the one that concerns us, the structure is more complex since, although the closure to the sea is carried out by a diverse dune system (Aigua Amarga-AltetArenals-Carabassí), towards the interior, the tectonic pattern multiplies and there are three wet zones that remain individualized among modest tectonic projections. Thus, between the two main elevations mentioned in the first place, the Aigua Amarga salt marsh, the Senieta salt marsh and the Clot de Galvany-Bassars are located from north to south. The elevations that rise between them are constituted by a calcareous crust and are identified with the area of L'Altet (name very expressive in spanish), Cabeçó and lomas del Carabassí (Marco 2006: 14-15). At present, the last one of the mentioned humid zones -Clot de Galvany-, is appreciated eloquently, through the observation of ortho-images of all type. The dark colors, linked to sheets of water and substrates very saturated in humidity and well covered with vegetation, define a strip from the inner edge of the dune system towards the west, surrounding the northern foothills of the cape within the Santa Pola mountain range.

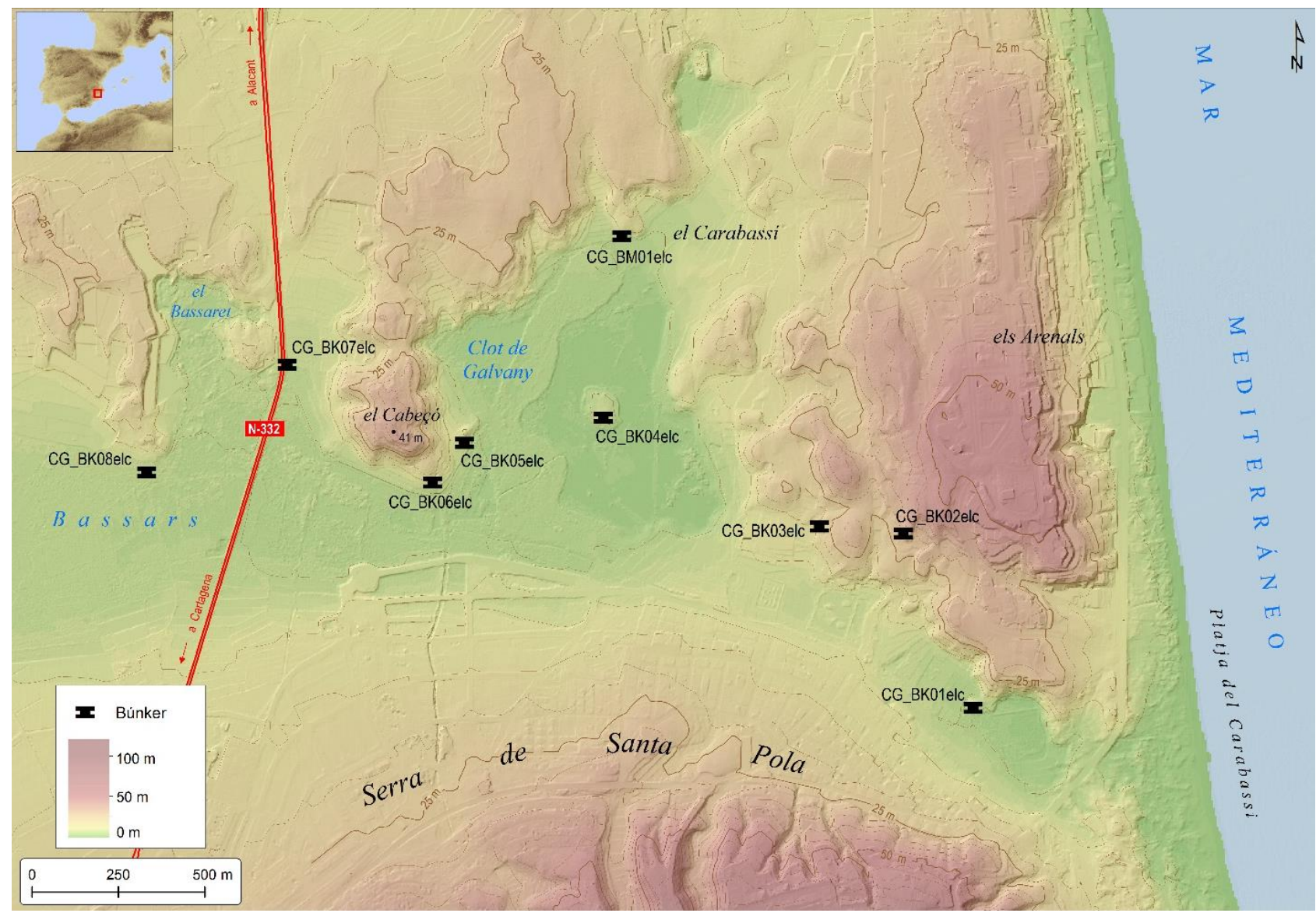

Figure 2. Map of the topography of the Clot de Galvany enclave where the 8 bunkers are located (the CG-BK04.elc is the largest and is located in the middle of the island of the lagoon). The Clot de Galvany is located in the lower part of the geography defined by the hills to the north (of lomas of Arenals and Cabeçó) and to the south (Santa Pola mountain range), connecting the beach of Carabassí with the National road N-332 (map: authors) 


\subsection{Description of the wet area of Clot de Galvany}

As we have already pointed out, the bunker object of the photogrammetric restitution is the main and larger one (fig. 3: CG-BK04.elc) of the Clot de Galvany military settlement (which takes its name from the natural site where this system of defenses is inserted). It constitutes one of the seven enclaves considered in the province of Alicante (Martínez, Juan 2015). Here the bunkers are located on the northern edge of this wetland, perched, to a greater or lesser extent, to the hills and small headlands that, abruptly, dominate the bottom of the tectonic depression occupied by the Clot de Galvany-Bassars with unevenness up to $35 \mathrm{~m}$. It is in those projections or at the foot of them where the bunkers are located, many of them camouflaged with the terrain. The situation of the 8 small structures that remain is strategically measured to neutralize a penetration from the sea that, taking advantage of the corridor configured by the current wet zone, pretended to progress towards the north, that is, towards the city of Alicante, reaching the road -that is only $2 \mathrm{~km}$ from the beach (fig. 2).

What is striking is the fact that the system was raised to defend a space that, due to its current condition, would be impassable and unfit for the passage of vehicles and even people. However, as can be seen from some previous work (Marco 2005), the attribu- tes that characterize this sector as a humid area are currently blurred when the situation of this space is contrasted in the middle of the 20th century, since practically all the space was occupied by crops and only the Clot de Galvany and the Bassaret were areas identified as wetland. Progressively, more reduced in extension is the wet zone if the frames (corresponding to series of the American flight of 1956 and those of Ruiz de Alda of 192930) are analyzed.

In fact, Box Amorós (2004) emphasizes that this space, as a floodable area, raised the need for its drainage and desiccation to put in cultivation all its surface. In fact, this author points out that the last attempt took place in 1919, although it did not materialize in any project for economic reasons. However, the aerial photographs of the flight of Ruiz de Alda, on the edge of the 30s, show that the extent reached by the crop was total since, the Clot de Galvany appears reduced to its minimum expression at that time. In any case, it was configured a space fully suitable for the transit of all types of vehicles, as was the new weaponry that was being tested in the war. Thus, the natural enclave, due to its topographic and geological conditions, invited the landing, but, at the same time, it offered conditions to mask the bunkers that went unnoticed.

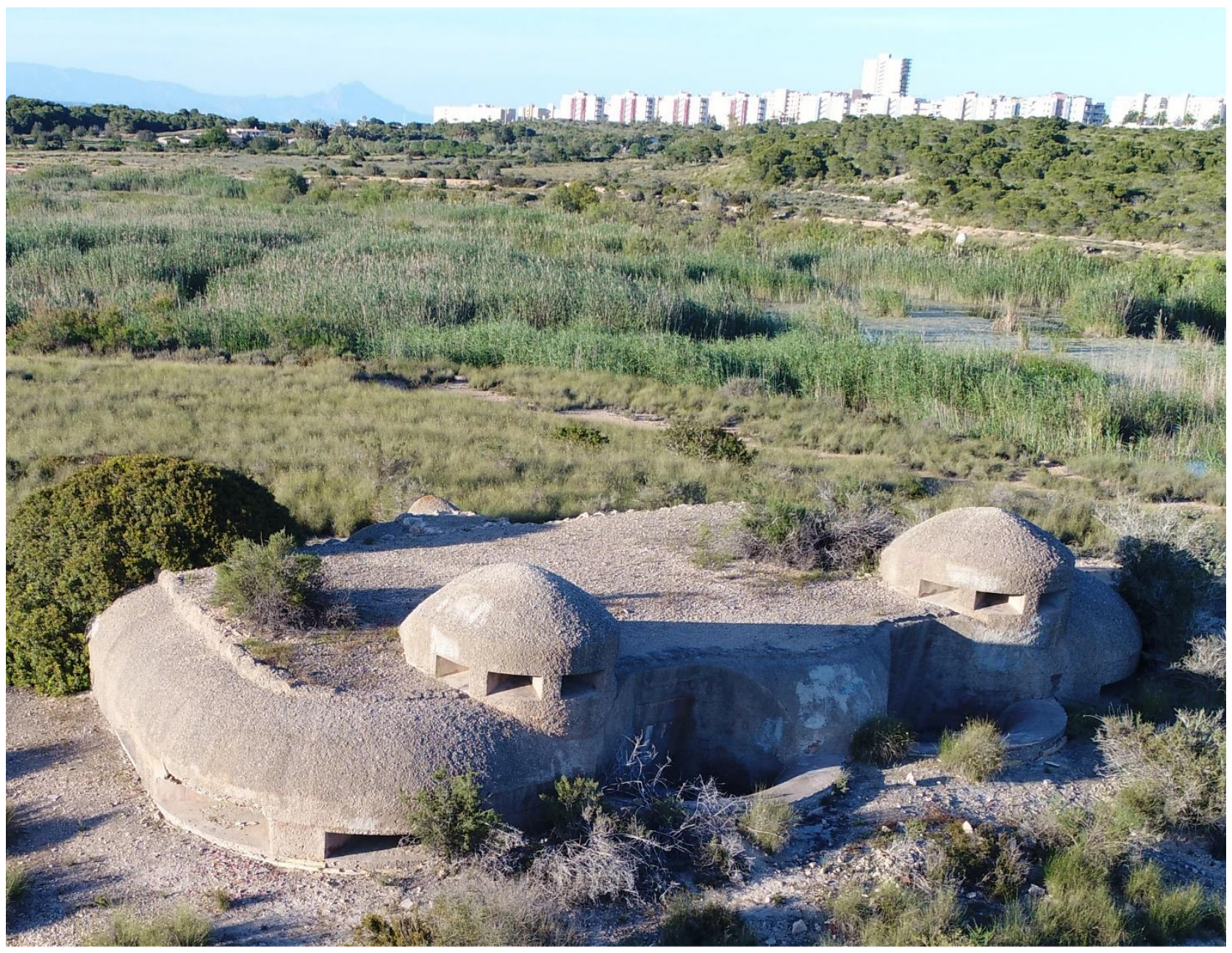

Figure 3. Current photography of the main bunker (CG-BK04.elc) taken from the drone; in the foreground the southern front with various defensive elements (loopholes, hatches and pits); behind are the hills of Arenals and Cabeçó, the tourist developments and, in the background, the Puig-Campana in the mountain ranges north of the province of Alicante (photo: authors) 


\section{THE PROCESS OF DIGITAL RESTITUTIONS}

\subsection{Field work for the military headquarter}

Original drawings, of this defensive settlement of the civil war, are not conserved in the military archives. The site was considered important because, apart from the political propagan$\mathrm{da}$, the detachment was constituted, at least, by a total of 10 bunkers (of 1 or 2 breasts, of different sizes and typological solutions), a military barracks for resting of the troop (known as 'la mulera'), two trenches on the west side of the national road and, even, outside the enclave itself in the north direction (about $300 \mathrm{~m})$ there are still three anti-aircraft and anti-tank systems (Martínez 2016). In fact, nowadays, the corresponding department is studying, including the set of the coast batteries along the Santa Pola cape, the possibility of declaring it protected heritage (Generalitat 2017). Therefore, graphically document, one by one, the concrete and masonry fortresses of this detachment constitutes a previous and necessary phase to recover this technical and material legacy of engineering and architecture of the 20th century. And for this, the team, which has initiated a research project that faces all the warlike heritage scattered along the coast of the Valencian Community, has decided to draw by photogrammetry the main bunker of the enclave which, as has already been highlighted, occupies a tactical position (in the middle of an island that appears and disappears depending on the drought) and, by its shape and measures, is unique since there is no other similar in the different fronts and battlefields along the Mediterranean coast.

\subsection{Equipment for photogrammetric survey}

Given the aforementioned conditions of accessibility and morphology of the element to be represented, it was decided, from the first moment, to take the photographic data by means of the help of unmanned aircraft. The aerial photographs of the bunker that are reproduced (figs. 3 and 4), as well as all the other snapshots with which we composed the dense points cloud, were made with the Phantom 3 and 4 (models of the company DJI) drone. The number of shots and the most important characteristics of them are reproduced in table 1. It is important to underline the condition of the database that acquires this graphic set: from the moment of its consideration, the drawing becomes referenced to them, in as much as containing information, and, by extension (but secondarily), to the physical object (Juan 2017). The climatic conditions of the two flights that were carried out, the height above the object, the reference coordinate system and the size of the pixels have also been specified.

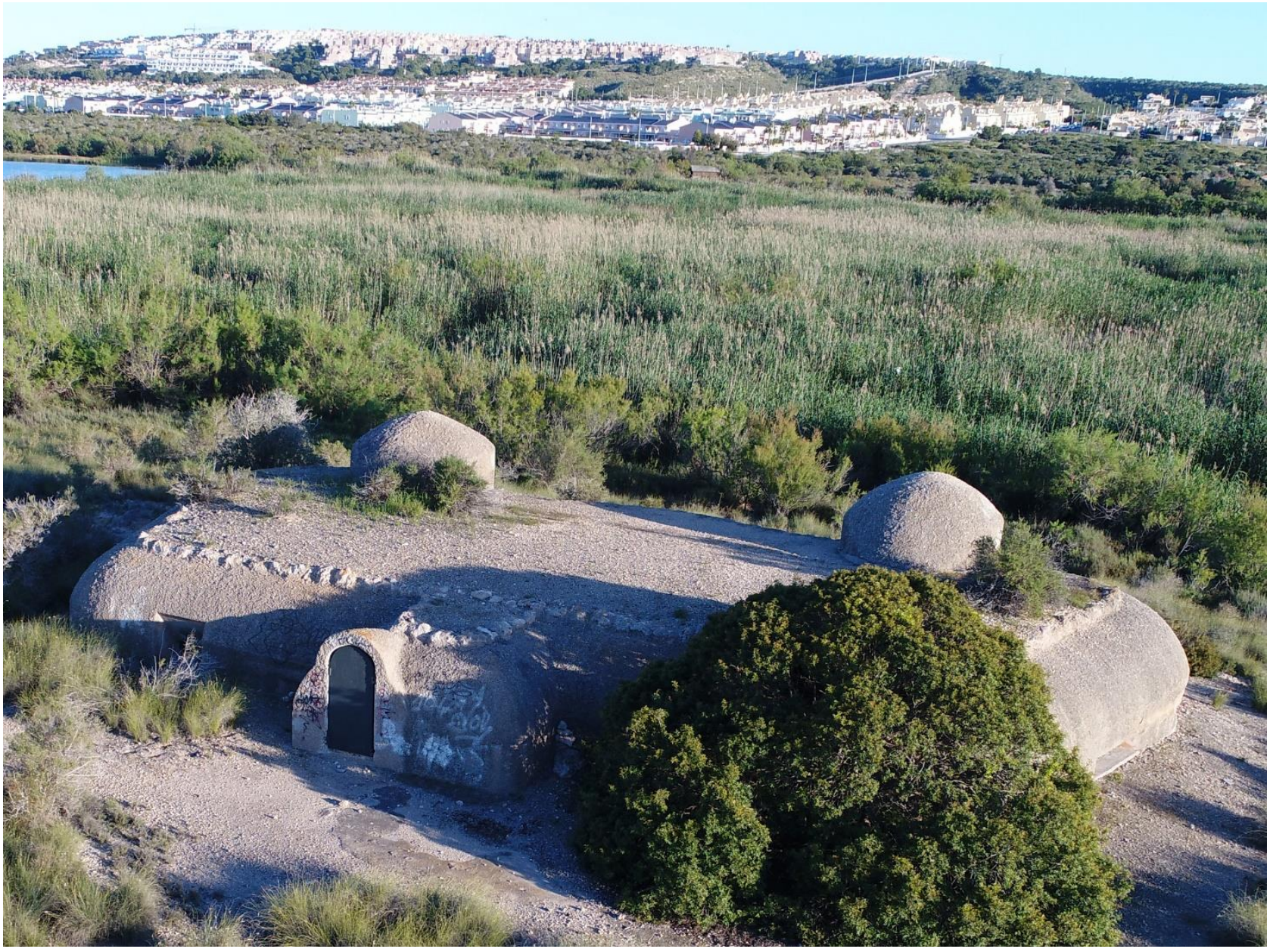

Figure 4. Current photograph of the main bunker (CG-BK04.elc) taken from the drone; in the foreground the northern front of the bunker with the only access to its interior and the upper surface (with the volumes of the hatches protruding); behind, the lagoon and, in the background, the tourist urbanizations on the mountain range and the cape of Santa Pola (photo: authors) 


\begin{tabular}{|l|c|c|}
\hline Characteristics & Vuelo 1 & Vuelo 2 \\
\hline Camera model & FC300X & CMOS \\
Number of Photos & 284 & 284 \\
Average height (m) & 15,1 & 14,9 \\
Focal length (mm) & 20 & 20 \\
Pixel size (microns) & $1,5 \times 1,5$ & $1,56 \times 1,56$ \\
Coordenate system WGS & 84 (EPSG: 4326) & ídem \\
Date of capture & $17 / 03 / 19$ & $18 / 05 / 19$ \\
Capture time & $18: 00$ & $14: 00$ \\
Weather conditions & Sunny & Cloudy \\
\hline
\end{tabular}

Table 1. Characteristics of the photographic database.

Due to, being in the middle of a marsh, it was impossible for us to gain access to the property at the time of the flights, we programmed a flight that swept the entire surface exterior with more photographs than the necessary ones, with the help of the aircraft and without losing sight of it.

\subsection{Data and databases of drone flights}

In a photogrammetric context, the workflow necessary to obtain the final result is far from being autonomous and independent of our interests and capabilities. In the case at hand, after selecting the photographs and making the necessary masks to obviate the irrelevant information, all our decisions were aimed at obtaining a final model with the minimum noise or deviation of their points. In Table 2 we observe the specifications of each of the scenarios with which we carry out the work. Note the data of 3 million points in the second flight: the time used to obtain it, compared with the relative error and its correspondence with the first flight, makes us emphasize the importance of the purpose and, in any case, the scale required at the end. In our concrete case, weighing these two parameters we show the suitability of the first flight versus the second, except for one variable: the climatic conditions. Logically, the cloudy day will allow us to represent, not only the shape, but the color of the material (and its texture) in a more precise way than, for example, in another moment in which the shadows of the textured model are the protagonists of the reading of the color (fig. 5).

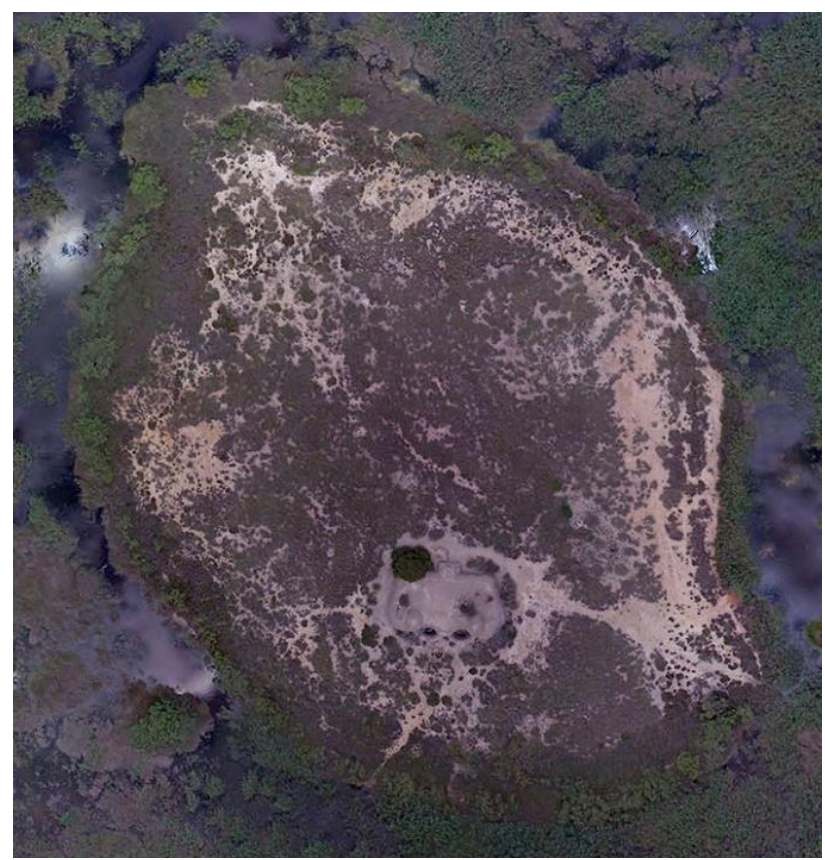

Figure 5. Aerial view (ortho-photograph) of the surroundings of the bunker, we can see 'the island' when it becomes rainy season

\begin{tabular}{|l|c|c|}
\hline Characteristics & Flight 1 & Flight 2 \\
\hline Point cloud (scattered) (N1) & 569.886 & 599,673 \\
Point cloud (dense) (N2) & 4.706 .282 & $39,607,395$ \\
Num. of faces of the model & 941.185 & $2,640,390$ \\
Num. of vertices of the model & 471.917 & $1,326,110$ \\
Size of the texture & $4.096 \times 4.096$ & ídem \\
Software & Agisoft- & -Metashape \\
Platform & Windows- & -64 bit \\
Processing time (N1+N2) & 8 hours & 30 hours \\
Processing time (model) & 1,5 hours & 4 hours \\
\hline
\end{tabular}

Table 2. Characteristics of digital models.
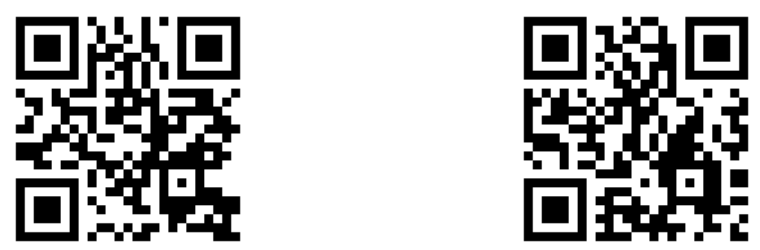

Figure 6. Links to the renders through QR codes.

The graphic results have been shared in the digital repository Sketchfab (https://sketchfab.com/) whose access data are in figure 6 . In them we can orbit in real time, as if it were a virtual flight, around the resulting models (mesh plus projected texture). The morphology of the bunker is appreciated in the same way that the pieces of a sculpture are experienced: by sequence and overlapping views.

With respect to figure 7 we have placed two views taken directly from the Agisoft Metashape Professional program. In them we see the combination between the position (and direction) of the cameras and the model obtained thanks to its processing. The strategy of orbiting around a centre (which has given good results in homologous drawings) has been combined, as can be observed, with a series of positioning on a regular mesh or grid. These two ways of capturing information have been combined with a third way in which the position of the photographs has been arranged ad-hoc, guiding us by the casuistry of the morphology and the conditions of the place.

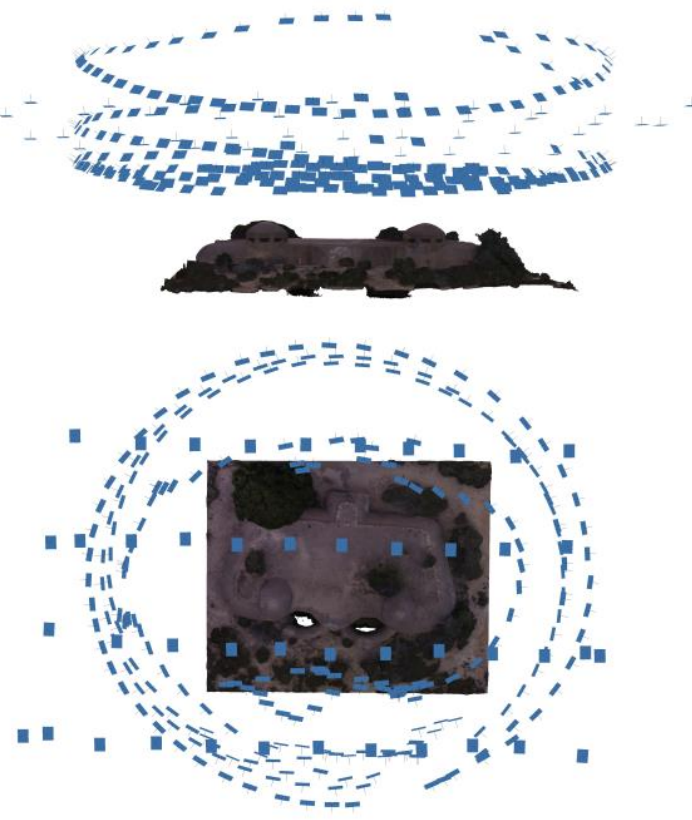

Figure 7. Position of the cameras around to the model (authors) 


\subsection{Some reflections on the digital drawing of the bunker} Selecting (not only those data that adequately mean the subject of the drawing, but also the strategy for the representation itself) is truly a challenge of contemporaneity. The postproduction possibilities of the textured model, once captured in our computers, are endless. Whether to calculate the surface with rigor, determine the family of colors of the constituent material of the architectural or engineering object (in this case the bunker) or perform a taxonomy of the different textures, the starting point has been moved from the untranslatable reality to a cloud of millions of points (in our specific case between 4 and 30 million).

In addition, this information is a graphic document that verifies and certifies (as if it were a notarial act) the state of the matter at a specific moment in time and, precisely for that reason, an undoubted and inherent starting value to the generated document. Our case is not different: the importance, the centre of gravity, however much we re-elaborate the information, will always be in the linked models of millions of points (positions) qualified (in color). Now, this information is of the external volume, that we would have to complete with the data of the interior that, by the dimensions of the bunker have taken of in a manual way to be able to link inside and outside in a single modeling.

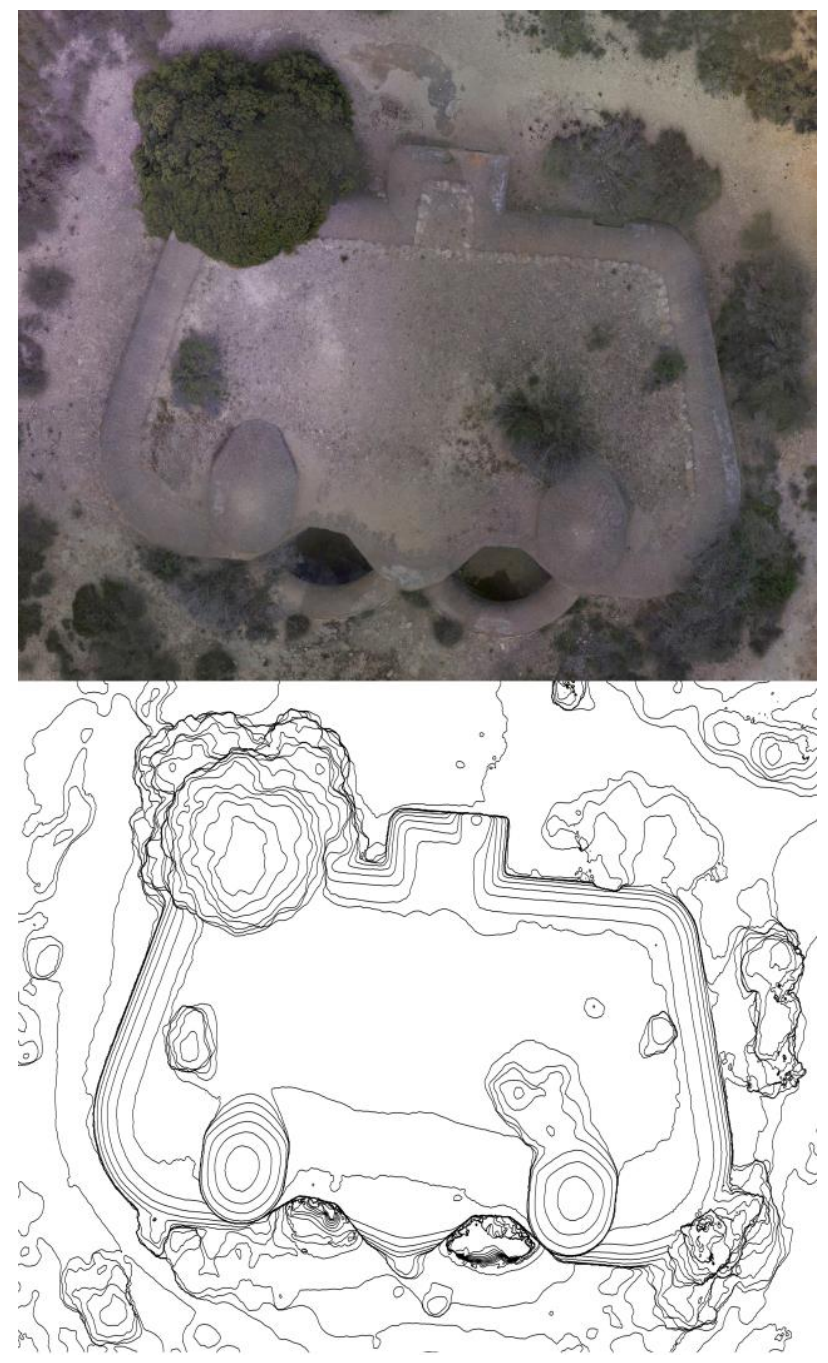

Figure 8. Different ways to filter the collected information: textured top view and level curves (photo \& drawing: authors)
In figure 8 we have two possible results of the external form, obtained thanks to the data from the drone flight and the linked software. The first (top image) is a bunker scaled top view (by way of aerial photography), created from the photographs projected on the thousands of faces that make up the generated mesh. The second represents the bunker as if it were a protuberance of the ground, so it is drawn as a topographic map, an idea that is in the genesis and execution of these petrified defensive machines that, part at the time of construction, they try to merge with the terrain (through its contours or through the matter of the final layer of the coating) to disappear before the eyes of aviation or enemy troops. Therefore, the way to represent this second image, being consistent with the above, would be to understand it as part of the terrain itself and, therefore, using the same tools used with this: level curves.

During the different approaches to the representation of the bunker, we detected that, in an academic context of rigor and precision, the vegetation and the surrounding terrain is an indelible and inseparable parameter without which the construction loses its condition of temporal actuality. This concept can be observed, not only during the analysis of the top view with the level curves, but also, and especially, in Figure 9, where we can distinguish different cross sections arranged as a sequence. As it has been a tradition since the late twentieth century, the sequence to which the vertical section cuts refer to the idea of representation (of millimeter precision) of reality as it is experienced. We emphasize, through this way of drawing, the contemporary reality in front of the idealized reality of the original drawings of orthogonal projections of industrial pieces (disappeared, but existing at the time of their construction). Finally, and to end with these reflections on the design of the bunker, we should note that our current computer equipment allows us to represent shapes by points without having to depend on the omnipresent line (Juan 2017).

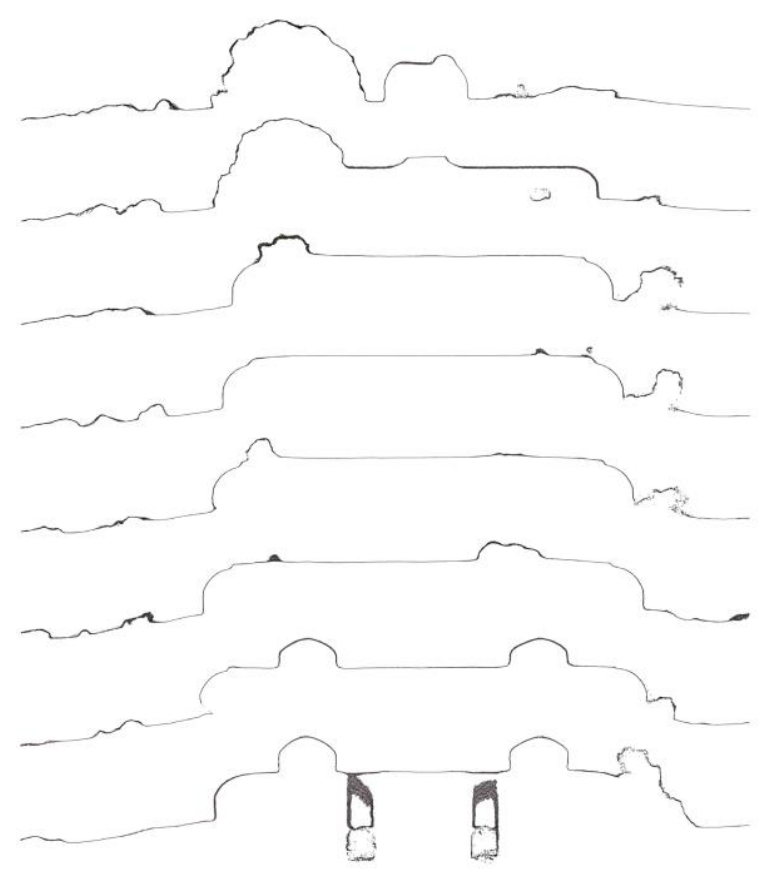

Figure 9. Vertical sections explaining complexity (drawings: authors) 


\section{CONCLUSIONS: AN OUTDOOR MUSEUM}

The technique of photogrammetry has allowed us to obtain the exterior of the bunker with high quality and precision, however, its interior space (constituted by small and interconnected rooms, in which the buttress walls are those that compartmentalize the distribution of the floor plan) is easier to measure from autographed tools and techniques. The drawing of the two bunker floors has required the combination of drone flight data and an on-site campaign (fig. 10). Among the highlights of this bunker (that reveal its graphic restitution) would be:

1) Its shape resembles a twin-engine with wide wings extended (close to imaginary of the interwar architectural vanguards),

2) Its surface, $204 \mathrm{~m} 2$, is one of the largest of the bunkers built by the Mediterranean Wall,

3) Its rigorous and elementary geometry links it with the typologies of the concrete small forts of Atlantikwall (Military 1943, Rolf 1985 and 2008)

4) The proportion between built and useful area is $45-55 \%$, which denotes the robustness of the walls (which reach half the floor space)

5) The interior distribution is zoned so that in the previous part the rooms (pits, loopholes and hatches) for defense of the position are located and in the upper part are the rest rooms, armourer and intendance.

The combination of both data (exterior and interior) allows (in addition to the orthogonal projection standard planimetries) ren- ders (fig. 11) that illustrate, virtually, the open-air museum in which Clot de Galvany is expected to become in the future. Due to the number of pieces that remain standing ( 8 bunkers, 1 shed, 2 trenches and 3 anti-tank elements), its good conservation and the excellent camouflage conditions (using stones, slabs, gravel, sand and vegetation) outdoor museum can be an excellent idea (fig. 12).

However, the work carried out here to draw the main and most unique bunker in the Clot de Galvany enclave (CG-BK04.elc) shows us the way forward for the rest of defensive elements that are preserved in the enclave and are protected by a special plan (Tabar 2011), once the inventory work and autograph documentation has been completed, replacing the original plans that have disappeared. Beyond the romantic evocation of this type of ruins that Paul Virilio (1994) detected decades ago, digital restoration work will be available to visitors in the open-air museum of the Clot de Galvany enclave, offering a real and geometric documentation that inform of these singular architectures, perhaps the first ruins of reinforced concrete, that are a reflection of the technical and material culture in the middle of 20th century and that spread throughout Europe. Perhaps the reflections of W. Benjamin during those years are true when he affirmed that "Never exists a document of culture without it being at the same time of barbarism" (Benjamin 1973: 182).
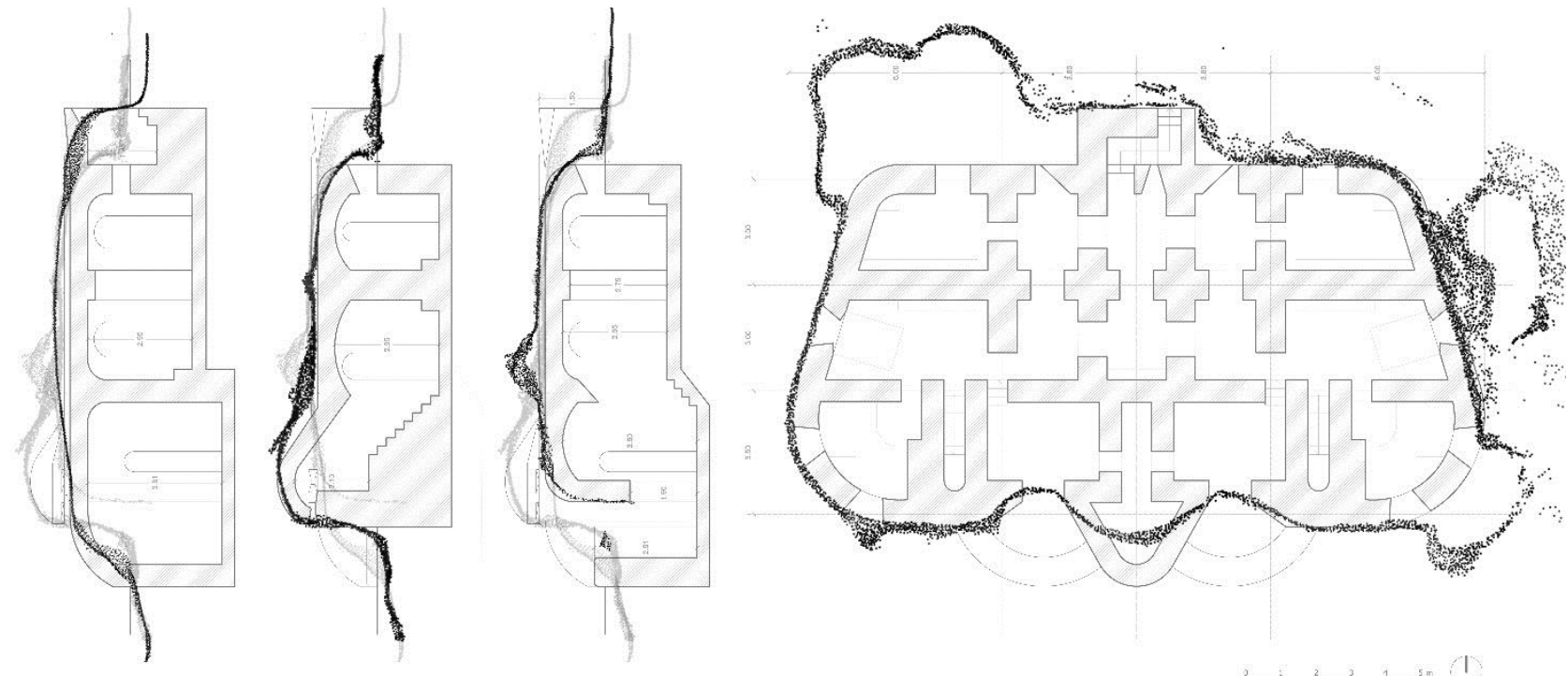

Figure 10. Top view and sections of the bunker CG-BK04.elc combining the photogrammetric work with traditional drawings. The irregularity of the reality, almost conforming a drawing of a natural or vegetal element, contrasts with the orthogonality and the precision that, without a doubt, established the original references of the $204 \mathrm{~m} 2$ during the construction. The defense zone in the front part (first division, where pits, loopholes, and hatches stairs are located) is distinguished of the refuge area in the back, where it descends by means of a stairway (drawings: authors)
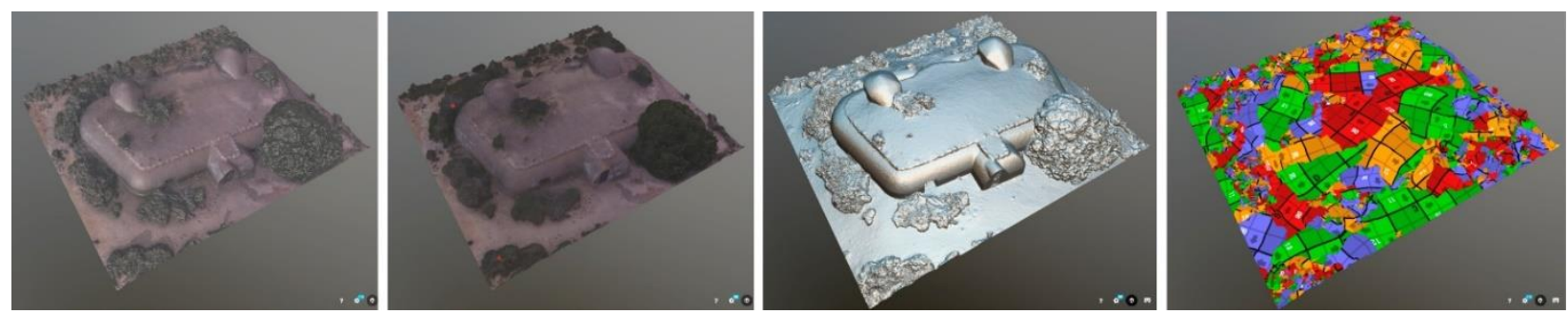

Figure 11. Frames of digital photogrammetric models, from left to right: rendering, texturing, metallizing and UV mapping. Extracted from the public repository where two models have been uploaded: https://skfb.ly/6KSBI y https://skfb.ly/6KWzX 


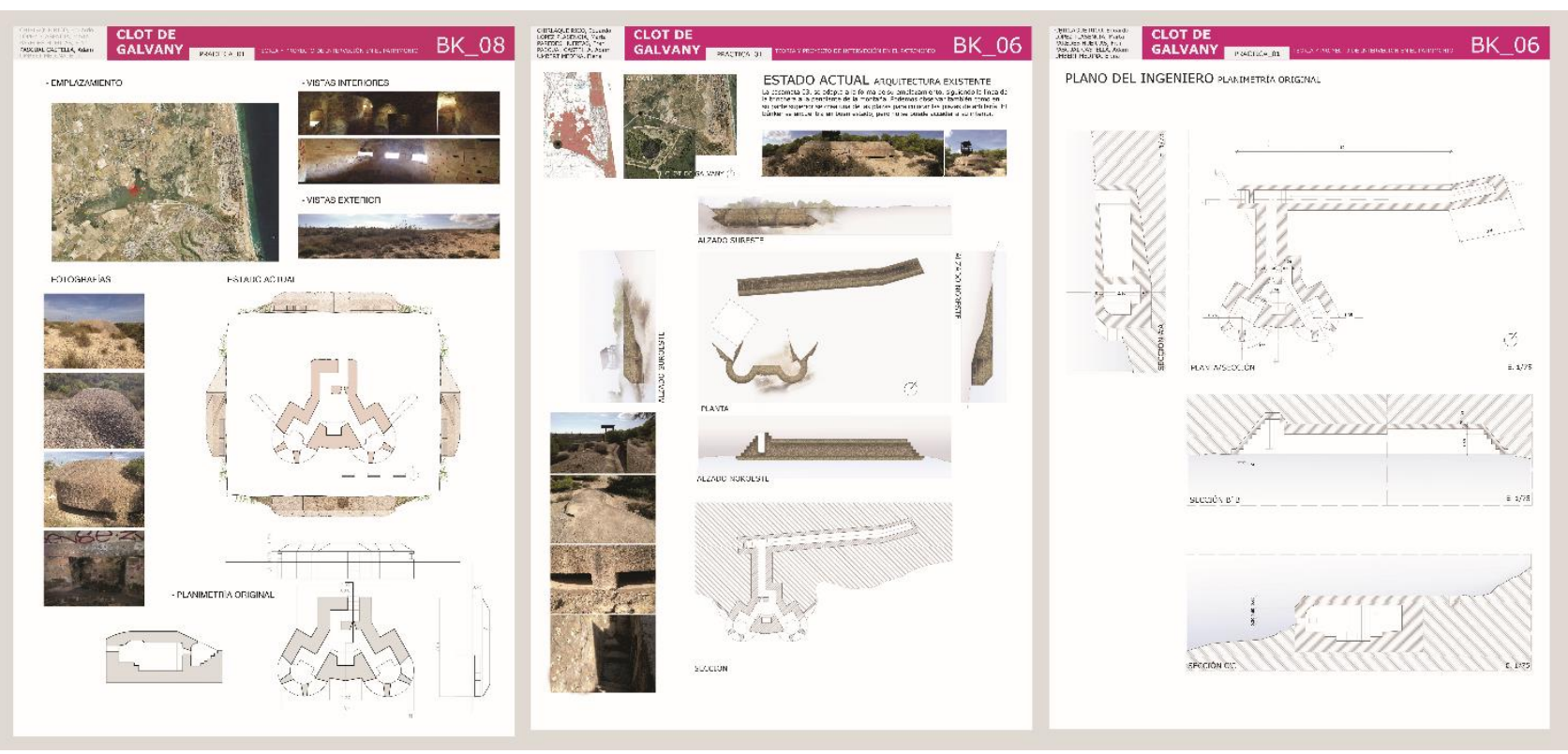

Figure 12.Part of the inventory of the defense elements of the Clot de Galvany to which will be extended the work of digital restitution of this military and industrial heritage, to put them in value through an interpretation center and an open-air museum

\section{REFERENCES}

Aracil, R.; Villarroya, J. 2010. El País Valencià sota les bombes (1936-1939). València: UPV.

Bartolomé Fernández, J. 1932. La fortificación de campaña en la defensiva. Burgos, Imprenta Aldecoa.

Benjamin, W. 1973 [1929-40]. Discursos interrumpidos I. Madrid, Taurus.

Box Amorós, M. 2004 [1987]. Humedales y áreas lacustres de la provincia de Alicante. Alicante: Universidad de Alicante.

Generalitat Valenciana 2017. Ley 9/2017, de 7 de abril, de la Generalitat Valenciana, de modificación de la Ley 4/1998, del patrimonio cultural valenciano [2017/3091]; DOGV núm. 8.019 de 11 de abril de 2017.

Gil Hernández, E.; Galdón Casanoves, E. 2007. El patrimonio material, in Girona Albuixech, A.; Santacreu Soler, J. (coords.), La Guerra Civil en la Comunidad Valenciana (vol. 17\%). Alicante: Prensa Alicantina.

Hernández Pacheco, E. 1934. Síntesis fisiográfica y geológica de España. Trabajos del Museo Nacional de Ciencias Naturales, Serie Geográfica, núm. 38, 2 fasc., Madrid.

Juan Gutiérrez, P.J.; Marcos Alba, C. 2016. "Swapping lines for points: digital photogrammetry and graphic narrative", en $E G E$. Revista de Expresión Gráfica en la Edificación. 2016, 9, pp. 8895.

Marco Molina, J.A. 2005. Los humedales costeros del sur de Alicante: perspectiva evolutiva, In: J.F. Vera Rebollo (ed.) Jornadas del Bicentenario. Torrevieja 1803-2003. Alicante: Universidad de Alicante, pp. 33-54.

Marco Molina, J.A. 2006. Conjuntos morfoestructurales y elementos del relieve de las comarcas meridionales valencianas. In: P. Giménez et al. (eds.) Geografía Física y Medio Ambiente. Alicante: Asociación de Geógrafos Españoles, pp. 11-25.
Martínez Medina, A. 2012. Dibujando la arquitectura olvidada: las defensas militares de la Guerra de 1936-39, In: AA. VV.: Investigación Gráfica. Expresión Gráfica Arquitectónica. Actas: Comunicaciones y Pósters. València: UPV, 268-274.

Martínez-Medina, A. (dir.) 2016. Arquitecturas para la defensa de la costa Mediterránea (1936-1939). Alicante: Universidad de Alicante. Available from: http://hdl.handle.net/10045/81287

Martínez-Medina, A.; Juan Gutiérrez, P. J. 2015. "Muro Mediterráneo: búnkeres y baterías para la defensa del litoral (1936-1939)", In: Rodríguez Navarro, P. (ed.): Defensive architecture of Mediterranean. XV to XVIII Centuries. FORTMED 2015 (2), València: UPV, pp. 231-238. Available from: http://hdl.handle.net/10045/50355

Martínez-Medina, A. \& Sanjust, P. 2013. Muro Mediterráneo versus movimiento moderno. Innovación e Investigación en Arquitectura y Territorio, Rev. I2 (1). Available from: http://dx.doi.org/10.14198/I2.2013.1.02

Military Intelligence Division. 1943. Handbook on German Military Forces. Washington: War Department. Available from: https://archive.org/details/TM-E30-451

Rolf, R. 1985. Het Duitse fortificatie-ontewerp 1935-1945. Beetsterzwaag: AMA.9

Rolf, R. 2008. Atlantic wall typology - Typologie du mur de l'Atlantique - Alantikwall. Typenheft. PRAK Publishing.

Tabar Rodríguez, I. 2011. Plan Especial de Protección del paraje natural del Clot de Galvany, Ayuntamiento de Elche

Villar Molina, L. 1942. Manual de fortificación de Campaña, Madrid, Ediciones Ejército.

Virilio, P. (1994) [1975]. Bunker Archeology. Princeton Architectural Press. Nueva York. 